Vogt, P. R. \& Avery, O. E. 1974: Tectonic history of the Arctic Basins: partial solutions and unresolved mysteries. In Y. Herman (edit.) Marine geology and oceanography of the Arctic Seas, 83-117. Berlin-Heidelberg-New York: Springer.

Vogt, P. R., Ostenso, N. A. \& Johnson, G. L. 1970: Magnetic and bathymetric data bearing on sea-floor spreading north of Iceland. J. geophys. Res. 75, 903-920.

Vonderbank, K. 1970: Geologie und Fauna der Tertiären Ablagerungen Zentral-Spitzbergens. Norsk Polarinst. Skr. 153, $119 \mathrm{pp}$.

Institute of Geology, Polish Academy of Sciences,

Senacka 3,

31-002 Krakow,

Poland.

\title{
Stratigraphical and sedimentological studies of Triassic rocks in central East Greenland
}

\author{
Lars B. Clemmensen
}

The present study of Triassic rocks in Jameson Land and Scoresby Land and on Traill $\varnothing$ (fig. 21) is a continuation of the field investigation initiated in 1975 (Clemmensen \& Andreasen, 1976). The Danish Natural Science Research Council (SNF) provides funds for the investigation in progress.

The purpose of this note is to present a new lithostratigraphical subdivision of the Triassic rocks (fig. 22) and to interpret the depositional environments of the stratigraphic units.

\section{Jameson Land and Scoresby Land}

The Triassic rocks were studied from five camp sites and several sedimentological logs varying in length from $c .40 \mathrm{~m}$ to more than $1000 \mathrm{~m}$ were measured. Only the upper three formations in the Scoresby Land Group of Perch-Nielsen et al. (1974) will be described.

\section{Pingo Dal Formation}

The formation in Jameson Land and Scoresby Land is subdivided into the Rødstaken (below), the Klitdal and the Paradigmabjerg Members. The Sydkronen Member described as the uppermost member within this formation by Perch-Nielsen et al. (1974) was found to be poorly defined; rocks apparently belonging to this unit are more naturally included in the Paradigmabjerg Member and in the new Kolledalen Member of the Gipsdalen Formation.

As the three lower members of the Pingo Dal Formation are defined in agreement with Perch-Nielsen et al. (1974), they will not be described in detail here. 


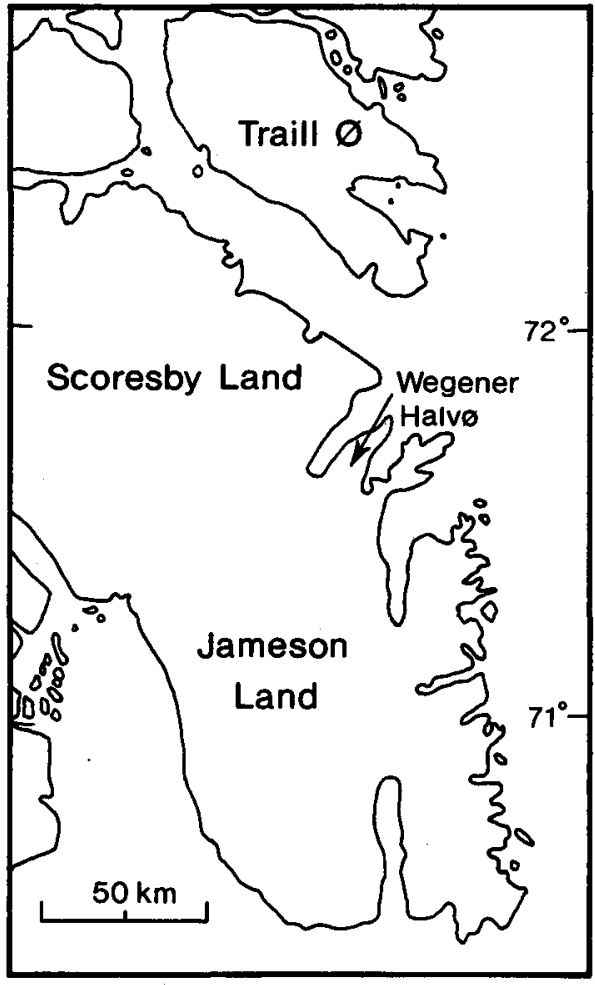

Fig. 21. Location map for Mesozoic studies in central East Greenland.

The bulk of the formation consists of coarse-grained sediments of alluvial fan origin, but some aeolian dune sandstones occur.

\section{Gipsdalen Formation}

Perch-Nielsen et al. (1974) divide this formation into a basal Solfaldsdal Member and an overlying Kap Seaforth Member. Type sections were measured by Grasmück \& Trümpy (1969), but Perch-Nielsen et al. (1974) use a definition of the boundary between the members somewhat differently than Grasmück \& Trümpy (1969). In order to overcome these discrepancies and to incorporate new data from the western part of the area it is suggested that the Gipsdalen Formation is dubdivided into the Kolledalen Member (new member), the Solfaldsdal Member (sensu Grasmück \& Trümpy, 1969) and the overlying Kap Seaforth Member (redefined).

\section{Kolledalen Member (new member)}

The member (up to $180 \mathrm{~m}$ thick) comprises light yellowish gypsiferous cross-bedded aeolian sandstones and associated sediments in the central and western part of the area. The member is most typically developed in the north-western part of the area, where it is overlain 
by the Kap Seaforth Member. In the central part of the area the member is overlain by a condensed Solfaldsdal Member; in the eastern part of the area it is missing.

The sediments are interpreted as alluvial fan, desert dune, floodplain, sabkha and shallow desert lake deposits. The dunes were probably deposited under the influence of trade winds (Clemmensen, in press).

\section{Solfaldsdal Member}

The member (up to $150 \mathrm{~m}$ thick) comprises the lowermost gypsum-bearing deposits in the south-eastern half of the area. As already noted by Grasmück \& Trümpy (1969) the member can be subdivided into three units: (a) basal unit with poorly exposed variegated gypsumbearing sandstones and siltstones, (b) a middle unit with fossiliferous limestones (the Gråklint Beds) and (c) an upper unit composed of reddish strongly bioturbated sandstones and siltstones with sparse gypsum nodules. The trace fossils in the upper unit include numerous feeding burrows and very rare Cruziana (Bromley \& Asgaard, 1972).

The gypsum-bearing sediments are interpreted as floodplain and sabkha deposits of a warm and evaporitic environment.

\begin{tabular}{|c|c|c|c|c|c|}
\hline \multicolumn{5}{|c|}{ JAMESON LAND AND SCORESBY LAND } & TRAILL $\varnothing$ \\
\hline GROUP & SUBGROUP & FORMATION & MEMBER & BEDS & MEMBER \\
\hline \multirow{8}{*}{$\begin{array}{l}\text { Scoresby } \\
\text { Land }\end{array}$} & \multirow{5}{*}{ Kap Biot } & \multirow{3}{*}{ Fleming Fjord } & Ørsted Dal & * Tait Bjerg & $\begin{array}{l}\text { S } \\
\text { Drsted Dal }\end{array}$ \\
\hline & & & Malmros Klint & & $\begin{array}{l}\text { S Malmros Klint } \\
\text { ? }\end{array}$ \\
\hline & & & Edderfugledal & * Pingel Dal & Edderfugledal \\
\hline & & \multirow[b]{2}{*}{$\triangle$ Gipsdalen } & - Kap Seaforth & & Kap Seaforth \\
\hline & & & $\begin{array}{c}\text { * Kolle- } \\
\text { dalen }\end{array}$ & * Gràklint & * Vega Sund \\
\hline & \multirow{3}{*}{$\begin{array}{l}\text { Nordenskiöld } \\
\text { Bjerg }\end{array}$} & $\triangle$ Pingo Dal & \begin{tabular}{l|l}
$\begin{array}{l}\text { Paradigma } \\
\text { bjerg }\end{array}$ & Klitdal \\
\end{tabular} & & \multirow[t]{2}{*}{ Paradigmabjerg } \\
\hline & & & Rødstaken & & \\
\hline & & \multirow[t]{2}{*}{ Wordie Creek } & & & $\begin{array}{l}\text { * Ødepas } \\
\text { * Svinhufvuds Bjerge }\end{array}$ \\
\hline & & & & & \\
\hline
\end{tabular}

Fig. 22. Preliminary lithostratigraphical subdivision of the Triassic rocks in central East Greenland. The stratigraphical subdivision of the rocks in Jameson Land and Scoresby Land constitutes a slight revision of the stratigraphical scheme proposed by Perch-Nielsen et al. (1974). The stratigraphical scheme for Traill $\varnothing$ builds on observations from the 1976 field season. 


\section{Gråklint Beds (new unit)}

The unit (up to $c .30 \mathrm{~m}$ thick) was discovered at a number of new localities both in the eastern, central and western part of the area. This makes it possible to correlate the gypsum-bearing deposits throughout the basin. The Gråklint Beds show considerable facies variations. In the centre of the area cliff-forming, commonly cross-bedded, sandy limestones dominate the upper half of the unit. Towards the north-east calcareous sandstones with wave-ripples and mud-cracks become frequent; elsewhere thin bitumen-rich limestones and mudstones are the most characteristic rock types. The unit is thickest in the central and north-eastern part of the area; it gradually wedges out towards the south-west and northwest. The north-eastern limit of the unit is unknown.

Bivalves, small gastropods and rare stegocephal remains (cf. Borborophagus wyomingensis det. S. E. Bendix-Almgreen, 1976) occur in the limestones and sandstones, whereas the black mudstones are rich in conchostracans. Grasmück \& Trümpy (1969) listed several fossils, the most important of which are, Myalina, Halobia, and Euestheria.

The fossil content of the Gråklint Beds is rather unusual in comprising marine bivalves in association with fresh-water conchostracans. It appears likely that the sediments were deposited in a restricted marine environment that periodically was cut off from the open sea and transformed into a lake.

\section{Kap Seaforth Member}

This member (up to $160 \mathrm{~m}$ thick) consists of cyclically bedded variegated sandstones and siltstones with gypsum sandstones, the latter often showing cross-bedding. In the northwestern part of the area the member overlies the Kolledalen Member. In the eastern and central part of the area the Kap Seaforth Member overlies the Solfaldsdal Member, and the lower boundary of the member is here defined in accordance with Grasmück \& Trümpy (1969) by a change from strikingly red, weakly gypsiferous sediments to variegated clearly cyclically bedded gypsum-rich deposits. The upper boundary of the member is defined in agreement with Perch-Nielsen et al. (1974).

The depositional environment is interpreted as a fluctuating lake. In periods where the lake dried out sand and gypsum were blown into small dunes (Clemmensen, in press).

\section{Fleming Fjord Formation}

This formation is divided into the Edderfugledal, Malmros Klint and Ørsted Dal Members by Perch-Nielsen et al. (1974). Present data enable the establishment of three new stratigraphical units of Bed-status.

\section{Edderfugledal Member}

The member was provisionally divided into two informal units by Clemmensen \& Andreasen (1976); a basal yellowish dolostone unit and an overlying variegated sandstonemudstone unit. In order to avoid a change in the stratigraphical rank of the Edderfugledal Member the two new units are given Bed-status. 
Sporfjeld Beds (new unit)

The unit consists of cyclically bedded dolomitic sandstones and mudstones, siliceous siltstones, stromatolitic limestones and rare oolitic limestones. The unit makes up the lower half of the Edderfugledal Member and often forms a single, up to $c .35 \mathrm{~m}$ thick, coarseningupwards sequence. Apart from very rare conchostracans no body fossils were found. Trace fossils occur in the upper part of the unit, where they are restricted to well-defined layers closely interbedded with non-bioturbated dolostones or stromatolitic limestones. The main trace fossils are: Lockeia, unilobate feeding burrows and very rare Cruziana. Pseudomorphs after rock salt are common in the non-bioturbated dolomitic sandstones.

The Sporfjeld Beds are interpreted as shallow-water lacustrine or occasionally lagoonal deposits. The salinity was generally high (evaporative dolostones, rock salt), but highly fluctuating.

\section{Pingel Dal Beds (new unit)}

The unit (c. 20-34 m thick) is characterised by the appearance of light grey, wave-rippled sandstones and red sandy mudstones, which occur closely interbedded with the rock types of the underlying Sporfjeld Beds. The sandstones and red mudstones display strong bioturbation. The main trace fossils constitute unilobate feeding burrows, Lockeia and numerous very small burrows and traces. The only body fossils found were small bivalves and conchostracans. The vertical arrangement of facies is very regular and can be traced laterally even in minor details over distances of $75 \mathrm{~km}$.

The sediments are interpreted as shallow-water lacustrine or occasionally lagoonal deposits. The lack of rock salt pseudomorphs, the less frequent appearance of synsedimentary dolomite and the increase in biogenic activity seem to indicate an overall decrease in the salinity.

\section{Malmros Klint Member}

The sedimentology of this member was studied in detail in 1975 (Clemmensen \& Andreasen, 1976). The member comprises red cliff-forming, fine-grained sandstones and siltstones and thins markedly towards the west and north-west. Trace fossils appear in abundance in parts of the member. Cruziana are frequent apart from the transitional zone to the Edderfugledal Member, where unilobate feeding burrows dominate. Fish remains (Gyrolepis det. S. E. Bendix-Almgreen, 1976) were also collected.

The sediments were most probably deposited in a large featureless lake. The salinity of the lake-water was generally low.

\section{Ørsted Dal Member}

The member is characterised by light-coloured, cross-bedded, often pebbly, locally arkosic, sandstones in association with red fine-grained sandstones and mudstones. Both mudstones and sandstones are commonly bioturbated, with various feeding burrows being the most common trace fossils. The sandstones commonly show intricated trough-formed 


\section{4}

channel-fill cross-bedding, planar sets being less common. The dominant sediment transport was either towards the east or south-east (western part of the area) or towards the north (eastern part of the area).

The uppermost part of the member consists of carbonate rocks - the Tait Bjerg Beds. The lower part of the member was most probably deposited in various fluvial environments.

\section{Tait Bjerg Beds (new unit)}

The lower part of the unit is characterised by the gradual appearance of silty limestones and variegated siltstones; the uppermost part of the unit consists of bitumen-rich dolomitic limestones and black mudstones with bivalves in association with limestone breccias containing vertebrate fragments. These uppermost bone-beds, in agreement with Grasmück \& Trümpy (1969), are chosen as the boundary between the Ørsted Dal Member and the overlying Rhaetic-Liassic Kap Stewart Formation. The limestones are well-developed in the eastern part of the area (up to 60-70 m thick) but could also be traced to the western part of the area.

The unit could represent a change from lacustrine to brackish-marine conditions.

\section{Traill $\emptyset$}

Triassic rocks on Traill $\varnothing$ were studied from two camp sites, one at Svinhufvuds Bjerge and one at Mols Bjerge (fig. 23). A third region, Morris Bjerge, was briefly studied during a reconnaissance flight.

\section{Wordie Creek Formation}

This formation occurs in Svinhufvuds Bjerge and presumably underlies younger Triassic deposits in the Mols Bjerge region. In Svinhufvuds Bjerge two new members, the Svinhuf-

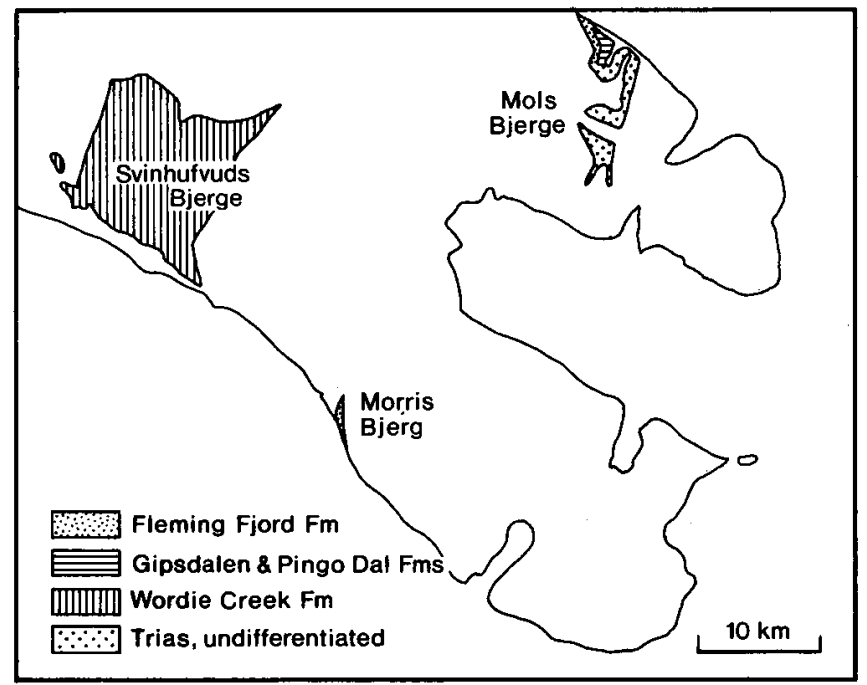

Fig. 23. Geological sketch map showing the distribution of Triassic outcrops on south-eastern Traill $\emptyset$, central East Greenland. 


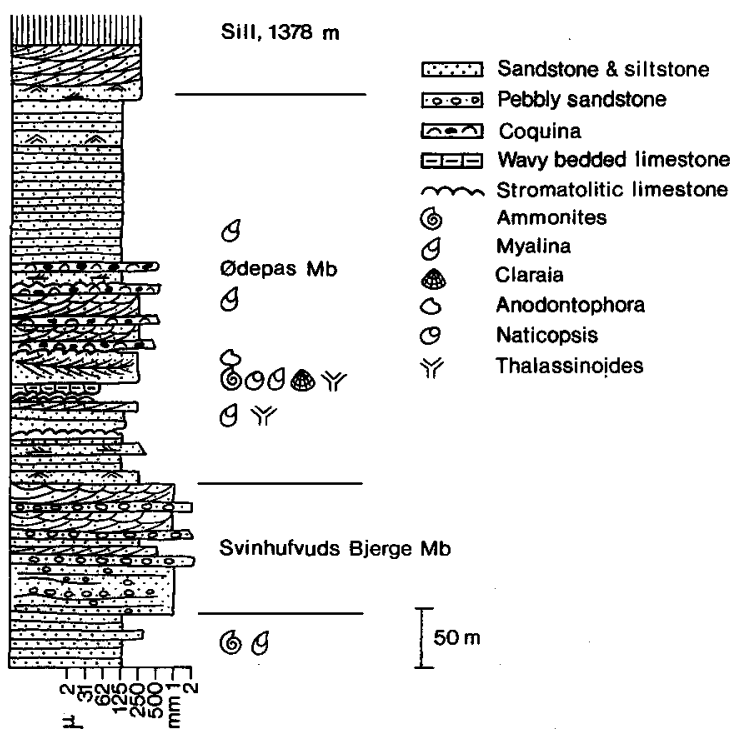

Fig. 24. Simplified sedimentological log of the uppermost Wordie Creek Formation, Svinhufvuds Bjerge, Traill $\emptyset$, central East Greenland.

vuds Bjerge Member and the overlying Ødepas Member (fig. 24) are recognised. Formal designation of these members will be made elsewhere jointly with $\mathrm{K}$. Birkenmajer.

Svinhufvuds Bjerge Member (new member)

The rocks included in this member were briefly described by Putallaz (1961) and consist of very coarse-grained often pebbly sandstones with cross-bedding everywhere showing transport towards east-south-east. No fossils were found. The thickness of the member reaches $c .125 \mathrm{~m}$.

The member represents the influx of very coarse clastic material during tectonic uplift in a western source area. The major part of the member is interpreted as fluvial.

\section{$\emptyset$ depas Member (new member)}

The member (c. $325 \mathrm{~m}$ thick) is initiated by dull reddish and greenish, very micaceous, sandstones and siltstones with brownish sandstone interlayers. In one of the latter horizons Mesolimulus tracks were observed. A middle cliff-forming unit constitutes stromatolitic limestones and wavy bedded limestones, coquinoid sandstones and cross-bedded sandstones. The unit is very fossiliferous (fig. 24) and the fauna includes bivalves (Myalina, Claraia, Anodontophora), gastropods (Naticopsis), and rare ammonites (Proptychites?) indicating a Scythian age. The upper part of the member constitutes reddish sandstones and siltstones with rare bivalves; the member is overlain by strikingly green cross-bedded sandstones (fig. 24), which form the uppermost deposits of the Wordie Creek Formation exposed at Svinhufvuds Bjerge.

The rocks in question are shallow marine and deposition took place in various subintertidal often wave-agitated environments. 
Pingo Dal Formation

This formation has only been recognised in Mols Bjerge, where it comprises a minimum of $100 \mathrm{~m}$ of red mudstones and pebbly, often cross-bedded sandstones of the Paradigmabjerg Member. The few palaeocurrent data indicate a dominant sediment transport towards the south. The formation is underlain by a several hundred metres thick sequence of gypsumrich brownish or greenish grey sandstones probably belonging to the Wordie Creek Formation.

The deposits are interpreted as fluvial.

\section{Gipsdalen Formation}

This formation has only been observed in Mols Bjerge, where it is c. $225 \mathrm{~m}$ thick. This recognition supports the ideas of Stauber (1942). The formation is divided into the basal Vega Sund Member and the overlying Kap Seaforth Member.

\section{Vega Sund Member (new member)}

The unit ( $c .125 \mathrm{~m}$ thick) is dominated by light yellowish, horizontally laminated weakly gypsum cemented, medium-grained sandstones. In the upper part of the member apparently unfossiliferous wave-rippled sandstones, black siltstones and thin limestones appear. This upper unit has certain aspects in common with the Gråklint Beds in Jameson Land and Scoresby Land. However, the lack of fossils in the Mols Bjerge sequence makes any correlation very dubious.

The yellowish sandstones were probably mainly deposited as aeolian sheet sands, whereas the upper unit with wave-rippled sandstones and black siltstones was deposited in shallow water.

\section{Kap Seaforth Member}

The member (c. $100 \mathrm{~m}$ thick) consists of cyclically bedded, yellowish sandstones and dark siltstones with gypsum cement overlain by poorly exposed variegated or bluish-grey occasionally gypsum-bearing deposits.

The member was deposited mainly in a shallow water, occasionally evaporitic environment. The lowest part was probably deposited under the influence of some aeolian activity.

\section{Fleming Fjord Formation}

This formation occurs both at Morris Bjerg and in Mols Bjerge. Whereas the Ørsted Dal Member crops out at the former locality, in Mols Bjerge only the Edderfugledal Member exists. The Malmros Klint Member has not been recognised on Traill $\varnothing$, but presumably underlies the Ørsted Dal Member at Morris Bjerg. 


\section{Edderfugledal Member}

The member (c. $100 \mathrm{~m}$ thick) comprises cliff-forming, greenish grey, yellowish brown or brownish cyclically bedded sandstones and siltstones with minor red muddy sandstones. Wave-rippled horizons, mud-cracks and stromatolitic intraclasts are common. However, stromatolitic limestones, so characteristic of the same member in Jameson Land and Scoresby Land, are completely missing. A few conchostracans were found.

The member is abruptly overlain by light yellowish, cross-bedded often pebbly sandstones of the mainly Middle Jurassic Pelion Member.

The Edderfugledal Member was deposited in very shallow wave-agitated water.

\section{Ørsted Dal Member}

The member is composed of at least $225 \mathrm{~m}$ of light greyish, often pebbly sandstones and reddish fine-grained sandstones and mudstones. The member is overlain by a thick sequence of yellowish sandstones of presumably Middle Jurassic age as suggested by Donovan (1953).

The deposits of the Ørsted Dal Member are interpreted as fluvial.

\section{References}

Bromley, R. G. \& Asgaard, U. 1972: Notes on Greenland trace fossils. Rapp. Grønlands geol. Unders. 49, $30 \mathrm{pp}$.

Clemmensen, L. B. in press: Alternating aeolian, sabkha and shallow lake deposits from the Middle Triassic Gipsdalen Formation, Scoresby Land, East Greenland. Palaeogeogr. Palaeoclimatol. Palaeoecol.

Clemmensen, L. B. \& Andreasen, F. 1976: Sedimentological observations in middle and late Triassic rocks, Jameson Land Basin, Central East Greenland. Rapp. Grønlands geol. Unders. 80, 106-110.

Donovan, D. T. 1953: The Jurassic and Cretaceous stratigraphy and palaeontology of Traill $\varnothing$, East Greenland. Meddr Grønland 111, 4, 150 pp.

Grasmück, K. \& Trümpy, R. 1969: Triassic stratigraphy and general geology of the country around Fleming Fjord (East Greenland). Meddr Grønland 168, 2, 5-71.

Perch-Nielsen, K., Birkenmajer, K., Birkelund, T. \& Aellen, M. 1974: Revision of Triassic stratigraphy of the Scoresby Land and Jameson Land region, East Greenland. Bull. Grønlands geol. Unders. 109 (also Meddr Grønland 193, 6) 51 pp.

Putallaz, J. 1961: Géologie de la partie Mediane de Traill Ö (Groenland Oriental). Meddr Grønland 164, $2,84 \mathrm{pp}$.

Stauber, H. 1942: Die Triasablagerungen von Ostgrönland. Meddr Grønland 132, 1, 325 pp.

Geologisk Museum, $\emptyset$ ster Voldgade 5-7, 1350 København $K$. 